\title{
THE EFFECT OF POLICY ON BUSINESS COMPETITIVENESS OF BALI CATTLE FARMING IN KUPANG DISTRICT, EAST NUSA TENGGARA, INDONESIA
}

\author{
Melkisedik Bukifan*)1, Harianto ${ }^{* *}$, Bayu Krisnamurthi **) \\ *Program Study Agribusiness, Faculty of Agriculture, Timor University \\ Jln Km 09 Kefamenanu, Timor Tengah Utara 85665,Indonesia \\ **)Department of Agribusiness, Faculty of Economics and Management, IPB University \\ Jl. Agatis, IPB Dramaga Campus, Bogor 16680, Indonesia
}

\begin{abstract}
Bali cattle are Indonesian indigenous cattle and bred by most households in East Nusa Tenggara (NTT) province. East Nusa Tenggara is one of the main production centers of beef cattle. However, the growth production rate of Bali cattle in NTT tends to decline, while Indonesian import rates of cow and meat are still increasing. This research aims to analyze the competitiveness level of Bali cattle. Policy Analysis Matrix was employed to determine the level of profit and competitiveness of cattle breeding at the household level, according to local agriculture officials, 140 breeders from 2 sub-district areas of Kupang were chosen as respondents. The results show that the cattle fattening farms have shown positive private and social profits and high level of competitiveness. Therefore, the appropriate government's policies toward the inputs and outputs are needed to increase the efficiency of Bali cattle production at household level.
\end{abstract}

Keywords: Bali cattle breeders, competitiveness, policy analysis matrix

\begin{abstract}
Abstrak: Sapi Bali adalah jenis ternak yang berasal dari Indonesia dan dibudidayakan oleh banyak rumah tangga di Provinsi Nusa Tenggara Timur (NTT). Nusa Tenggara Timur merupakan salah satu sentra produksi utama sapi potong. Namun demikian, tingkat pertumbuhan produksi sapi Bali di Nusa Tenggara Timur cenderung menurun, sementara impor sapi dan daging Indonesia meningkat. Penelitian ini bertujuan untuk menganalisis tingkat daya saing sapi Bali. Matriks Analisis Kebijakan digunakan untuk menentukan tingkat keuntungan dan daya saing peternakan sapi di tingkat rumah tangga berdasarkan informasi dari pejabat pertanian setempat, 140 petani dari 2 wilayah kecamatan Kupang dipilih sebagai responden. Hasilnya menunjukkan bahwa peternakan penggemukan sapi menguntungkan baik secara privat maupun sosial, dan memiliki tingkat daya saing yang tinggi. Oleh karena itu, kebijakan pemerintah yang tepat terhadap input dan output diperlukan untuk meningkatkan efisiensi produksi sapi Bali di tingkat rumah tangga.
\end{abstract}

Kata kunci: Daya saing, peternak sapi Bali, matriks analisis

\footnotetext{
${ }^{1}$ Corresponding author:

Email: melkibukifan@gmail.com
} 


\section{INTRODUCTION}

Bali cattle are one of the Indonesian indigenous beef cattle and have been bred in several provinces in Indonesia (Tanari, 2001). The breeding of Bali cattle in East Nusa Tenggara (NTT), especially in Timor Island, has been developed since the 1900s which were brought in by the Dutch colonial government from Bali Island (Herweijer, 1950). The cattle are adaptable to the environment with minimal feed availability (Sastradipradja, 1990), have a high-quality carcass yield and high reproductive rate (Payne and Hodges, 1997). Based on 2016 data from the Dinas Peternakan (Disnak) of NTT province, Timor Island has the largest population of Bali cattle in NTT, with a total population of 5.930 .000 head or $66 \%$ of the total cattle population in NTT.

The beef cattle production in Indonesia has experienced an average increase of $1.95 \%$ per year from 1984 to 2016 (Directorate General of Livestock and Animal Health Services (DGLAHS or Indonesian Ditjen $P K H$ ), Ministry of Agriculture (2017)). However, data observation from 2012 to 2016 shows the growth rate of cattle population is $1.13 \%$, and so there is a decline in the population growth rate. This was caused by a significant decline in population numbers, which amounted to $20.62 \%$ in 2013 compared to previous years. DPKH (2017) shows that meat consumption in Indonesia tends to increase due to population growth and income. Annual consumption growth rises by $5.69 \%$ from 2015 to 2016. Higher consumption growth compared to population growth can result in increasing imports to meet domestic demand, and increasing meat price in domestic market.

The beef price tends to rise from the price of IDR76,925 to IDR116,751 per kilogram from 2012 to 2016 with growth over the past five years amounted to $11.08 \%$ (DGLAHS, 2016). The phenomenon of the meat price uptrend is usually due to the high consumption of meat in seasonal, such as big days, religious, and national feast day. In 2016, the meat price was never returned to the starting position since the Eid al-Fitr until September 2016. This situation caused breeders cannot afford to respond to price changes that occur due to the long production cycle, simple breeding technology, and a part-time business. There are needs to restrain the beef price, so it is not surged sharply as of 2015, which drain the population of beef cattle and decrease local cow resources.
To overcome the shortage of meat supply, the Government of Indonesia issues a permit to import feeder cattle in 2014. DGLAHS data in 2017 shows the beef imports was 260,196 tons. The increasing of meat imports can have a negative impact on the development of domestic cattle farms and weaken food security. In 2014, the government sought to achieve beef self-sufficiency and encourages local governments to increase cattle populations in their respective regions through various policies or programs, such as prohibiting the slaughter of productive female cattle, increasing cattle insemination, implementing a quota system, and developing feed sources (DGLAHS, 2017).

A lot of research about the competitiveness of the cattle business have been done in Indonesia. Research by Perdana (2003) found that the business of cattle fattening is profitable socially and has a comparative advantage. In addition, there is no difference in profits level among the small, medium, and large cattle business. Widodo (2006) showed the management of Sistem Integrasi Peternakan Sapi (Cattle Farming Integration System, CFIS) has a comparative advantage with an indicator of domestic resources cost coefficient (DRCC) of 0.57. Sunandar (2006) conducted a study in Gunung Kidul district found that the business of beef cattle in Gunung Kidul has no comparative advantages with DRCC value larger than one (DRCC $>1$ ). Analysis by Handayani (2013) using policy analysis matrix (PAM) suggests that the business of cattle fattening or breeding in Indragiri Hulu district has a competitive and comparative advantage. However, the Handayani's study found that the removal of tariffs against imports may cause business of fattening to lose the competitive power.

The most influential factors on the competitiveness of beef cattle are the output price. The decrease in output price by $15 \%$ can cause business of beef cattle fattening to have no comparative advantage again. To face this condition, the government needs to find a solution as soon as possible before 2020, one of which by giving subsidies for domestic breeders. In addition, related to animal feed problems, integrating livestock-oil palm plantations programs should be more effective by providing assistance with feed processing machinery technology. It is expected that feed input costs can be reduced so that the profits received by farmers increase (Handayani, 2013). 
Although the population of Bali cattle in NTT began to show an increase, the number of cows ship to Java island still stagnant. The increasing price of cattle in the Java island has not been able to increase the supply of Bali cattle from NTT to Java island's market. In contrast, imported beef tends to increase in the Java market. Therefore, the question arises whether Bali cattle in NTT have competitiveness? If Bali cattle in NTT have competitiveness, the increase in demand for cattle from outside the province should be met by increasing the supply of cattle from NTT. This study aims to analyze the competitiveness and influence of government policies on the competitiveness of Bali cattle in Kupang district, NTT.

\section{METHODS}

The data used in this study are primary data obtained from 140 respondents of Bali cattle breeders in the two sub-districts of Kupang district, namely Amarasi and West Amarasi. The selection of respondents is based on information obtained from the office of Agriculture and Animal Husbandry, NTT province. Respondents was selected purposively with the criteria of respondents selected based on the main job, namely breeders whose main job is fattening Bali cattle.

Data obtained through interviews with respondents using a questionnaire. Primary data:

1. Livestock characteristics and raising techniques such as the use of labor and raising periods;

2. Business investment consisting of cages and equipment; and

3. Amount of usage and price of inputs, namely feeder cattle (initial weight, final weight, cattle buying and selling price), amount and price of forage and concentrate feeds, vaccines, medicines and vitamins, labor, economic age of pens, equipment, marketing costs, and transportation costs.

This research also utilizes secondary data from the literature or previous competitiveness studies as well as data sourced from the BPS and the office of Agriculture and Animal Husbandry of Kupang district and NTT province.

The collected data was analyzed using policy analysis matrix (PAM). The PAM method is widely used in analyzing the competitiveness of agricultural production. According to Pearson et al. (2005), the using of domestic resources and external resources are useful to find out the extent to which competitive and comparative advantages are approached. The PAM method measure the impact of government intervention on an economic activity, which in this study is the impact on beef cattle fattening business.

The assumptions used in PAM are: (1) production output is tradable, while inputs can be separated based on foreign factors (tradable) and domestic factors (non-tradable); (2) the input-output relationship and the relative price of production factors are constant; (3) market prices are actual prices received by breeders in which there are government policies or market distortion. The first stage of using the PAM method was the identification of inputs and outputs used for Bali cattle fattening. The second stage separated cost elements into tradable and non-tradable groups. This study used a total approach in allocating tradable and non-tradable input costs. The third stage calculated the revenue of Bali cattle fattening business, and the fourth stage was calculating and analyzing various indicators of comparative and competitive advantages in Bali cattle fattening business (Table 1).

Private profit is the difference in revenues with total costs based on private prices or actual prices that occur in the market. These prices can be influenced by government policies. Private profit was carried out to measure the level of competitiveness of a commodity system and can be used for analysis of benefits at the private price level or actual price (Pearson, 2005). Social benefit is the gap between the revenue and total costs at the level of social price or efficiency, which is based on estimates through field data on domestic market factors in the countryside. The aim is to find out some of the output or income lost because domestic factors are used to produce the best alternative commodities (Pearson, 2005).

\section{RESULTS}

\section{Profitability and Competitiveness of Bali Cattle Business}

The Bali cattle business is both privately and socially beneficial as shown in Table 2. Private benefits and social benefits were positive, accounted of IDR20,14 million and IDR5.82 million, respectively. The difference in the amount of private benefits compared to social benefits 
is mainly contributed by the calculation of non-tradable inputs. If calculated based on social values, nontradable inputs are far higher than their private values, accounted of IDR11.88 million. The difference in the calculation of non-tradable costs between private and social profit shows that breeders in Kupang district rely more on production inputs that are not purchased from the market, but rather they are obtained from within the household (subsistence). The Bali cattle breeders in Kupang district utilizes lamtoro as feed resources obtained from their garden or farm as the main feed for the livestock. Muthalib et al. (2010) said that the increasing of efficiency of input usage would lead to increase competitiveness.

The Bali cattle competitiveness was measured by calculating the domestic resources cost ratio (DRCR) for comparative competitiveness and the calculation of the private cost ratio (PCR) for competitive competitiveness. Table 3 presents the results of the calculation of the DRCR and PCR indicators on the Bali cattle business in Kupang district. The DRCR value of Bali cattle fattening in Kupang district was 0.77 . This value shows that the shadow value of the net domestic input in the Bali cattle business is smaller than the shadow value of the net tradable input. Hence, the Bali cattle business has a comparative advantage, because it only requires a domestic input of USD 0.77 to produce a value of USD 1. The PCR indicator also shows a magnitude smaller than 1 , which is equal to 0.28 . Based on actual (private) prices and the tradable input component is deducted from revenue, the Bali cattle business in Kupang district is able to produce a value of IDR100 by using domestic inputs of IDR28. Based on the PCR indicator, the Bali cattle business has a competitive advantage.

Table 1. Indicator calculation of policy analysis matrix (PAM)

\begin{tabular}{|c|c|c|c|c|}
\hline \multirow{2}{*}{ Indicators } & \multirow{2}{*}{ Revenue } & \multicolumn{2}{|r|}{ Cost } & \multirow{2}{*}{ Profit } \\
\hline & & Tradable Input & Factor Domestic & \\
\hline Private Price (market) & A & $\mathrm{B}$ & $\mathrm{C}$ & $\mathrm{D}$ \\
\hline Social Price (economy) & $\mathrm{E}$ & $\mathrm{F}$ & G & $\mathrm{H}$ \\
\hline Divergency (transfer) & $\mathrm{I}=\mathrm{A}-\mathrm{E}$ & $\mathrm{J}=\mathrm{B}-\mathrm{E}$ & $\mathrm{K}=\mathrm{C}-\mathrm{G}$ & $\mathrm{L}=\mathrm{D}-\mathrm{H}$ \\
\hline \multicolumn{5}{|l|}{ Efficiency and comparative advantage } \\
\hline Private profitabilities & & & $\mathrm{D}=\mathrm{A}-(\mathrm{B}+\mathrm{C})$ & \\
\hline Social profitabilities & & & $\mathrm{H}=\mathrm{E}-(\mathrm{F}+\mathrm{G})$ & \\
\hline Private Cost Ratio (PCR) & & & $\mathrm{PCR}=\mathrm{C} /(\mathrm{A}-\mathrm{B})$ & \\
\hline Domestic Resource Cost Ratio (DRCR) & & & $\mathrm{DRCR}=\mathrm{G} /(\mathrm{E}-\mathrm{F})$ & \\
\hline \multicolumn{5}{|l|}{ Policy distortion and market failure } \\
\hline Output Transfer (OT) & & & $\mathrm{I}=\mathrm{A}-\mathrm{E}$ & \\
\hline Input Transfer (IT) & & & $\mathrm{J}=\mathrm{B}-\mathrm{F}$ & \\
\hline Factor Transfer (FT) & & & $\mathrm{K}=\mathrm{C}-\mathrm{G}$ & \\
\hline Net Policy Transfer (NT) & & & $\mathrm{L}=\mathrm{D}-\mathrm{H}$ & \\
\hline Nominal Protection Coefficient on Output (NPCO) & & & $\mathrm{NPCO}=\mathrm{A} / \mathrm{E}$ & \\
\hline Nominal Protection Coefficient on Input (NPCI) & & & $\mathrm{NPCI}=\mathrm{B} / \mathrm{F}$ & \\
\hline Effective Protection Coefficient (EPC) & & & $\mathrm{EPC}=(\mathrm{A}-\mathrm{B}) /(\mathrm{E}-\mathrm{F})$ & \\
\hline Profit Coefficient (PC) & & & $\mathrm{PC}=(\mathrm{A}-\mathrm{B}-\mathrm{C}) /(\mathrm{E}-\mathrm{F}-\mathrm{G})$ & \\
\hline Subsidy Ratio Producer (SRP) & & & $\mathrm{SRP}=\mathrm{L} / \mathrm{E}$ & \\
\hline
\end{tabular}

Table 2. Revenue, costs, and private and social benefits of the 5-tailed Bali cattle business based on PAM analysis

\begin{tabular}{lcccc}
\hline \multirow{2}{*}{ Variable } & Revenue & & Cost & Profit \\
\cline { 3 - 4 } (million IDR) & Tradable input (million IDR) & Factor Domestic (million IDR) & (million IDR) \\
\hline Private Price & 51.99 & 24.17 & 7.67 & 20.14 \\
Social Price & 46.50 & 21.17 & 19.50 & 5.82 \\
Divergence & 5.49 & 3.00 & $(11.88)$ & 14.32 \\
\hline
\end{tabular}

The number indicated in the bracket is negative number 
Table 3. Results of calculation of comparative and competitive competitiveness of Bali cattle business

\begin{tabular}{lc}
\hline Competitiveness Indicator & Value \\
\hline Domestic Resources Cost Ratio (DRC) & 0.77 \\
Private Cost Ratio (PCR) & 0.28 \\
\hline
\end{tabular}

The results of this study are not much different from the results obtained by some previous researchers whose DRC and PCR values were less than one, such as Yuzaria and Suryadi (2011), Indrayani (2011), Hayandani (2013), and Rouf (2014). However, different results showed by the findings of Lestari at al. (2016) who stated that the business of fattening beef cattle in Bojonegoro district is not beneficial both competitively and comparatively. This condition is caused due to the high costs that breeders must pay both at market prices and social prices. Ilham and Yusdja (2004) said that domestic beef is more expensive than imports, with regard to high marketing costs. It seems that the cost of transportation is high, the weight of cattle is reduced during transportation, levies, and illegal levies. Harianto (2013) stated that the current condition of the logistics system of beef cattle in Indonesia still shows poor performance, reflected in the difficult and expensive costs of shipping cattle in Indonesia. Further solutions can be proposed to overcome the problems of beef logistic systems such as: (1) addition of the number and type of transportation facilities, (2) provision feeder or beef cattle, (3) providing complete ports with cold storage, and (4) integration of policies among ministries, the localgovernment, and private sectors. Therefore, improvements in the Indonesian logistics system must continue to be carried out to increase the competitiveness of beef cattle in Indonesia.

In this research, the DRC value of 0.77 is almost close to 1.00 which is different from the PCR value of 0.28 which is close to zero. The basic assumption that if the DRC and PCR values close to zero then certain commodities will be competitive both comparatively and competitively, vice versa. As a result, the value of the DRC approaching 1.00 can mean the need to increase efficiency so that each unit of domestic economic input is able to provide higher economic output values. While the PCR value of 0.28 which is near to zero means that the Bali cattle business is financially feasible to be developed in Kupang district. Access to Bali cattle breeders for funding sources needs to be continuously improved.

\section{Influence of Policy on the Bali Cattle Business}

The policy of a commodity is usually related to actions that affect the output prices of domestic commodities so that they are different with commodity prices on world markets. There are several assumptions used in the implementation of commodity policies, namely commodities can be traded internationally; transfer fees are very small; and market failures and changes in demand and supply do not affect world prices. There are two direct policy instruments in the field of animal husbandry, namely subsidy policy and trade policy. The subsidy policy is related to the flow of government budget and intended to increase breeders' access to production inputs and a wider market output. This policy certainly can cause the actual price at the breeder level to be different from the shadow price that should be paid or received by breeders. Whereas the trade policy implemented by the government is limiting the import of feeder cattle and beef which can enter the domestic market (Monke and Pearson, 1989). Government policies are carried out to achieve the basic goals of efficiency, equality, and resilience. Efficiency can be obtained when sharing scarce resources in the economy generate a maximum profit and allocation of goods and services provide the highest satisfaction for consumers. The expected equity in the profit distribution among various groups of people in several regions is the focus of policy makers. Whereas, resilience, for example food security, refers to avaibility of food supply at a stable and affordable price level (Pearson et al. 2005). Gupta (2009) stated that, besides being influenced by productivity, the competitiveness of a commodity can be influenced by government policies. Government policies can also be indirect, such as policies for improving infrastructure, tax policies, or also policies that affect the exchange rate of the Rupiah.

Table 4 presents the influence of government policies on the input and output of the Bali cattle business in Kupang district. The government's policy on the business of the Bali cattle in Kupang district has a positive impact. The transfers value is IDR5.49 million and the nominal output protection coefficient is 1.11. This result shows that government policy distortions 
that cause private prices are higher than their social prices. The results of the study show that the value of Output Transfer (OT) is positive, which means that the selling price of domestic feeder cattle is more expensive than its international price. The results of this study are not much different from those found by Lestari at al. (2016) on fattening beef cattle in Bojonegoro district, East Java province.

The Indonesian government's policies on output are protective, this can be proven with the nominal protection coefficient on output (NPCO) value is more than one $(\mathrm{NPCO}>1)$. There are several previous studies such as Muthalib et al. (2010), Indrayani (2011), Yuzaria and Suryadi (2011), Haitami (2012), Rouf (2014), and Lestari at al. (2016). The OT is closely related to the NPCO, which is the ratio of private price acceptance to social acceptance. NPCO value of the Bali cattle in Kupang district show more than one. In actual conditions, the Bali cattle breeders receive 1.11 times higher revenue than the social prices. The price of the cattle in research locations ranges from IDR29,500-31,500 per kilogram of live weight, while imported feeders cattle ranges from IDR24,000-26,000 per kilogram of live weight.

The influence of government policies on production inputs can be distinguished based on traded inputs (tradables) with non-tradable inputs. The government policy influences producers in the form of subsidies or taxes on tradable inputs while non-tradable inputs affect producers and consumers. The effect of subsidizing inputs can increase the use of inputs and benefit producers, and vice versa. Muthalib et al. (2010) argued that tradable inputs have causality towards competitiveness, namely the more efficient use of inputs, the greater the competitiveness, the increase in efficiency of one unit will increase competitiveness by 0.63 units. Likewise, with the efficiency of labor wages, the more efficient the labor force, competitiveness is expected to be higher.

The impact of government policies can be seen from the indicators of the value of inputs transfer (IT) and transfer factor (TF). If the value of the input transfer is positive then there is a government policy that causes input prices to be more expensive than the social price, and vice versa. The policy impact on inputs can also be seen from the indicator of the nominal protection coefficient on input (NPCI) value. If the nominal coefficient on input (NPCI) value is more than one (NPCI $>1$ ), then the breeder must pay the actual input price more expensive than the social price, and vice versa. Table 4 shows the positive value of IT in the Bali cattle business, which is Rp3.07 million. This is due to the existence of taxes and levies on tradable inputs, which is also indicated by the fact that private prices for cattle are lower than the social price. TF is an indicator that shows the difference in value in private prices with the social price received by breeders to pay for non-traded production factors. The value of TF in the fattening business of Bali cattle in Kupang district is -IDR11.83 million. This means that government policy has resulted in breeders paying domestic inputs cheaper than their social prices. NPCI is the ratio between costs calculated based on private prices and social prices. Based on the results of the research on the Bali cattle fattening in Kupang district, the NPCI value is 1.14. This shows that the fattening of Bali cattle in Kupang district has private input costs that are higher than the costs that should be paid. This means that government policies have not run effectively, and tend to burden Bali cattle breeders.

Table 4. Indicators of the government policies influence on the input and output of the Bali cattle business with a business size of 5 animals

\begin{tabular}{|c|c|}
\hline Indicator & Value \\
\hline \multicolumn{2}{|l|}{ Output: } \\
\hline Output Transfer (OT) & IDR5,499,643 \\
\hline $\begin{array}{l}\text { Nominal Protection Coefficient on } \\
\text { Output (NPCO) }\end{array}$ & 1.11 \\
\hline \multicolumn{2}{|l|}{ Input: } \\
\hline Transfer Input (TI) & IDR3,007,000 \\
\hline Transfer Factor (TF) & (IDR11,833,929) \\
\hline $\begin{array}{l}\text { Nominal Protection Coefficient on } \\
\text { Input (NPCI) }\end{array}$ & 1.14 \\
\hline \multicolumn{2}{|l|}{ Input-Output: } \\
\hline Net Transfer (NT) & IDR14,326,571 \\
\hline Effectife Protection Coefficient (EPC) & 1.09 \\
\hline Profitability Coefficient (PC) & 3.46 \\
\hline Subsidy Ratio to Produsen (SRP) & 0.30 \\
\hline
\end{tabular}

The number indicated in the bracket is negative number 
The impact of government policy on input-output is a combination of input policies and output policies. The impact of policy on input-output can be seen from the value of effective protection coefficient (EPC), net traffic (NT), profitability coefficient (PC), and subsidy ratio to producer (SRP). The EPC value illustrates the extent to which government policies are effective in protecting domestic production. If the EPC value is less than one $(\mathrm{EPC}<1)$, then the policy does not work effectively or inhibits the producer from producing and, vice versa. Table 4 illustrates that NT is an indicator that explains the effect on producer surplus. The NT value received by breeders in the Bali cattle business in Kupang district is Rp14.32 million. This means that transfers received by tradable input breeders and domestic factors are greater than the transfers given to consumers. The value of EPC is more than one, which means that there is protection from the government against breeders. PC is an indicator to measure the impact of all transfers on private profits. PC explains the impact of incentives on all output policies and tradable input policies and domestic inputs. The PC value in Table 4 which is 3.46 illustrates that the profits received by breeders are smaller than the social benefits.

The value of SRP is an indicator that shows the level of addition or reduction in revenues from the exploitation of a commodity due to government policies. The value of SRP in the Bali cattle business in Kupang district is 0.30 . This shows that the current government policy causes breeders in Kupang district to release production costs 30\% lower than the economic value. The results of this study are higher than those found by Muthalib at al. (2010) with the value of SRP of $4 \%$, Handayani (2013) with a value of SRP 28\%, and Rouf (2014) with a value of $2.3 \%$.

\section{CONCLUSIONS AND RECOMMENDATIONS}

\section{Conclusions}

The business of Bali cattle fattening in Kupang District benefits both privately and socially. This explains that the Bali cattle fattening business still benefits breeders even though without government policy. The business also has competitiveness, both competitively and comparatively. This can be seen from the DRC value of 0.77 and PCR of 0.28 . Government policies on outputs and inputs for the fattening of Bali cattle in Kupang district provide positive incentives for breeders.
Government policy also provides protection for Bali cattle business.

\section{Recommendations}

Improving Bali cattle breeding and increasing breeders' access to input and output markets are expected to continue to be part of government policy in the field of Bali cattle business. Consequently, Bali cattle production are able to increase and pursue increased demand for beef.

\section{ACKNOWLEDGMENTS}

The author would like to thank the Ministry of Research, Technology, and Higher Education and Indonesia Endowment Fund for Education (LPDP), Ministry of Finance for funding this research. We thank government of NTT province and Kupang district for providing data and information related to this research.

\section{REFERENCES}

[Disnak] Dinas Peternakan. 2016. Populasi Sapi di Nusa Tenggara Timur. Kupang: Dinas Peternakan Provinsi Nusa Tenggara Timur.

[DPKH] Direktorat Jenderal Peternakan dan Kesehatan Hewan. 2016. Pedoman Pelaksanaan Upaya Khusus Sapi Induk Wajib Bunting (Upsus SIWAB 2017). Jakarta: Kementerian Pertanian.

[DPKH] Direktorat Jenderal Peternakan dan Kesehatan Hewan. 2016. Statistik Peternakandan Kesehatan Hewan. Jakarta: Kementerian Pertanian.

Gupta SD. 2009. Comparative Advantage And Competitive Advantage: An economics perspective and a synthesis.: Toronto, 2009 May 29-31: 43rd Annual Conference of the CEA. Canada. Toronto (CA) CAE. pp 1-19.

Haitami PS. 2012. Analisis daya saing dan efisisensi penggemukan sapi potong di Kabupaten Lampung Tengah Provinsi Lampung [thesis]. Lampung: Universitas Lampung.

Harianto. 2013. Mengatasi problematika pasokan daging sapi. http://seskab.go.id/artikel-10312. html. [12 Mar 2018].

Ilham N, Yusdja Y. 2004. Sistem transportasi perdagangan ternak sapi dan implikasi kebijakan di Indonesia. Analisis Kebijakan Pertanian 2(1):37-53. 
Indrayani I. 2011. Analisis produksi dan daya saing usaha penggemukan sapi potong di Kabupaten Agam Provinsi Sumatera Barat [thesis]. Bogor: Sekolah Program Pascasarjana, Institut Pertanian Bogor.

Handayani S. 2014. Analisis daya saing usaha peternakan sapi potong dan usaha budidaya ikan patin di Kabupaten Indragiri Hulu Provinsi Riau. Jurnal Manajemen \& Agribisnis 10(3):137145.

Herweijer CH. 1950. Enkele aantekenigen btreffende de geschiedenis van de runderveeteelt op het Eiland Timor. Hemera Zoa 56: 689.

Lestari RD etal.2017. Analisis daya saing penggemukan sapi potong di Kabupaten Bojonegoro Jawa Timur. Buletin Peternakan 41(1): 101-1012.

Monke EA, Pearson SK.1989. The Policy Analysis for Agricultural Development. Itacha: Cornell University Press.

Muthalib et al. 2010. Dampak kebijakan pemerintah terhadap daya saing dan efisiensi serta keunggulan kompetitif dan komparatif usaha ternak sapi rakyat di kawasan sentra produksi Provinsi Jambi. Humaniora 12:55-62.

Payne WJA, Hodges J. 1997. Classification Systems for Cattle Breeds. In Tropical Cattle: Origins, Breeds and Breeding Policies; Hodges J, Payne WJA (Eds). Oxford: Blackwell Science. pp 89 94.

Pearson S, Carl G, Sjaiful B. 2005. Aplikasi Policy Analysis pada Pertanian Indonesia. Jakarta: Yayasan Obor Indonesia.

Perdana T. 2003. Competitiveness and comparative advantage of beef cattle fattening in Bandung District. http://www.standford.edu/group/FRI/ indonesia/html. [20 Feb 2018].
Rouf AA. 2014. Analisis daya saing sapi potong di kabupaten Gorontalo. Jurnal Pengakajian dan Pengembangan Teknologi Pertanian 19(2):103118.

Sastradipradja D. 1990. Potensi internal sapi bali sebagai salah satu sumber plasma nutfah untuk menunjang pembangunan peternakan sapi potong dan ternak kerja secara nasional. Prosiding. Seminar Nasional Sapi Bali; Denpasar: 20-22 September 1990. Denpasar: Fakultas Peternakan Universitas Udayana. Hlm A-47-A-54.

Sunandar, Nandang. 2006. Keunggulan komparatif usaha ternak sapi potong di kabupaten Gunung Kidul. Agros 8:43-45.

Tanari M. 2001. Usaha pengembangan sapi bali sebagai ternak lokal dalam menunjang pemenuhan kebutuhan protein asal hewani di Indonesia. http:// rudyct. 250x. com/sem1_012/m_tanari. htm. [12 Dec 2018].

Widodo S. 2006. Keunggulan komparatif usaha sapi potong di Kabupaten Bantul. Di dalam: Mathius IW, Sendow I, Nurhayati, Murdiati TB, Thalib A, Beriajaya, Suparyanto A, Prasetyo LH, Darmono, Wina E, penyunting. Cakrawala baru IPTEK menunjang revital peternakan. Prosiding Seminar Nasional Teknologi Peternakan dan Veteriner. Bogor, 5-6 September 2006. Bogor: Puslibangnak. hlm 268-277.

Yuzaria D, Suryadi D. 2011. Analisis tingkat keuntungan, keunggulan kompetitif, keunggulan komparatif dan dampak kebijakan impor usaha peternakan sapi potong di Provinsi Jawa Barat. Journal Agripet 11:32-38. 